\title{
Asian, African and Middle Eastern Legal Materials at SOAS Library
}

\begin{abstract}
Sarah Spells provides information about the SOAS Library, including details of the law collection, services offered, and the challenges faced when dealing with queries about Asian, African and Middle Eastern legal materials.

Keywords: legal systems; Asia; Africa; Middle East; academic law libraries; academic law librarians
\end{abstract}

\section{Introduction}

If you need to find a copy of the Indian Penal Code, case reports from Hong Kong, legislation from Ghana, or other fascinating legal texts, try contacting the Library at the School of Oriental and African Studies (SOAS).

SOAS is one of the colleges of the University of London and was founded in 1916. It is unique in that it is the only higher education institution in the United Kingdom specialising in the study of Asia, Africa and the Middle East. The School has approximately 200 academic staff, who are the leading experts in their fields of study, and around 3,700 students from more than 100 countries. The School of Law is situated within the Faculty of Law and Social Sciences. Most members of the academic staff possess (or acquire) expertise in one or more of the systems of law and legal institutions of these regions. The Law School also has particular strengths in a number of fields, including comparative law, human rights, transnational commercial law, environmental law, globalisation in relation to law and conflict resolution.

The School's library is the national resource for the study of Asia, Africa and the Middle East and caters for many different teaching and research needs. The Library contains over a million volumes (including the archives and manuscripts in Special Collections), over 4000 periodicals and a vast array of electronic resources.

\section{The School of Law}

The Law School currently teaches around 400 students and offers various undergraduate and postgraduate degrees. The LLB and BA (a joint degree in law and a language or another discipline) include the core modules in areas of UK law (such as contract, tort etc), but also modules in the Legal Systems of Asia, Africa and the Middle East, Law and Society of Asia and Africa and Ethnic Minorities and the Law. Therefore, even first year students have to learn various areas of law from different legal systems and require extensive legal research training.

The Law School offers a specialist range of LLM and MA degrees, as well as MPhil and

Sarah Spells PhDs, many of which, in their subject and focus, are
unique in the UK. They cater for individuals looking to develop skills in specialised areas relating to law in a global and developing world context.

The Law School also participates in a number of special programmes within the School and the University, including various MA degrees in regional studies; MA in International Studies and Diplomacy; and MSc in Finance and Financial Law. It is also home to a thriving research community including the East Asian Law Centre; the Centre for Ethnic Minority Studies; the Centre of Islamic and Middle Eastern Law; the Centre of International Law and Colonialism, and the Sir Joseph Hotung Project on Law, Human Rights and Peace Building in the Middle East.

\section{Library collection}

Thanks to the extension of the north and east terraces of the library last year, the Law collection has been provided with extra shelving space in which to grow, plus more work stations for users. Previous visitors may remember 
the library having a very dingy atmosphere due to the cramped space and concrete walls. The current expansion has changed this enormously and the SOAS library is now a lighter, brighter area more conducive to study.

The Library develops and maintains primary and secondary legal material on the countries of Asia, the Middle East and Africa, excluding the Roman-Dutch jurisdictions (held at the Institute of Advanced Legal Studies). We collect material in European, Asian and African languages and include current legislation and law reports. SOAS Library is particularly strong on customary law, Islamic law (most of which is in Arabic), and the laws of China and South Asia (India, Pakistan, Bangladesh and Sri Lanka). We also collect material on jurisdictions outside Asia and Africa, including English and European law (where they are needed to support teaching).

It would take me all day to list all the major publications SOAS subscribes to, so highlights include access to a large collection of Indian legal materials such as the All India Reporter, Bombay Law Reporter and Kerala Law Times. We also collect the All-Pakistan Legal Decisions and many regional Official Government Gazettes.

As regards Chinese materials, SOAS subscribes to the Isinolaw database which is an online guide to the laws and regulations of the People's Republic of China. It includes national and local laws and regulations, judicial interpretations, court judgments, daily updated legal news and Taiwan and Macau laws (in Chinese only). The database can be searched in Chinese, Japanese or English.

The Library catalogue and other useful information can be found at http://www.soas.ac.uk/library. However, to find out whether SOAS holds particular primary materials, I suggest using the FLAG database available at http://ials.sas.ac.uk/library/flag/flag.htm. This is an excellent resource and contains descriptions of collections of foreign and international primary law materials held in print format by libraries in the UK.

\section{Library services}

The School attracts students from all over the world and I deal with a wide range of undergraduate and postgraduate students, with varying legal research skills and experience. I also deal with students from other institutions studying an area of law that only SOAS caters for. Queries I receive range from the very basic "Where can I find this journal..." to requests for help researching specific areas of law within Asia, Africa and the Middle East, as well as the UK, EU and US. For example, one of the more interesting queries involved finding legislation on witchcraft for particular African countries.

As well as guiding SOAS students to the right resources, I also help other law librarians, solicitors, barristers and even judges. Most queries are simple requests for a particular case report or a piece of legislation, such as the Muslim Family Law Ordinance or the Commercial Code for Turkey. Other queries are more vague and just require information about a particular subject. For example, one request was to help find information on diversity in broadcasting in Africa, and another on organ transplants in Iran.

Probably the most difficult aspect of helping anyone new to SOAS (be it new students or members of the public) is trying to explain the classification system, especially when describing how to find the book on the shelves whilst making sure they actually understand you! I'm sure those who have already visited SOAS could tell you the "unique" style of classmarks we use (for those who were wondering, it's loosely based on the Dewey system). For the uninitiated all I can say is that it might look confusing at first, but you soon get the hang of it! Any new visitor needing help should approach the Enquiry Desk staff, who are often seen guiding lost souls to the right floor.

The SOAS Library allows entrance to visitors of all shapes and sizes, with many different categories of membership, depending on your status (for example, a staff member at a UK University or a member of the public interested in human rights etc.) More information is available on the website at http://www.soas.ac.uk/ library/index.cfm?navid $=254$. Basically, any member of the public is allowed into the library free-of-charge as long they have photo identification and they're doing noncommercial research.

If you decide to visit SOAS in person, we do provide a photocopying service. Just remember to bring some $\ell \mathrm{I}$ coins with you to purchase a card and credits. If you are unable to come into SOAS, we also provide an Interlibrary loan service for external customers requesting a copy of material held in the SOAS Library. All requests for photocopies must comply with UK copyright law and are supplied by post; unfortunately there is no fax or electronic delivery available. More information and details of costs are available on the Library website.

\section{The Law Librarian}

I came to SOAS over three years ago and I have to admit, it's been a steep learning curve. Despite working for an institution renowned for its Asian, African and Middle Eastern legal materials, I began with no knowledge or expertise in these areas. I do, however, have an LLB which has certainly come in handy. I actually started my career believing I was going to qualify as a solicitor, although once I completed my LLB in 1999, I became a little disheartened about spending the rest of my life in the cut-throat world of the legal profession. After working in a small academic law library, I discovered the joys of librarianship and I'm now able to use my legal knowledge to help others in their own research.

Unfortunately, my background also does not include being able to read Arabic, Chinese or Japanese etc. This 


\section{Sarah Spells}

presents a small problem when ordering and cataloguing material, and answering some queries. For example, if someone requests information about a particular item written in a non-western language, I won't be able to help personally, but I do know someone who can. There are many specialist regional librarians who can assist when necessary, and the academics themselves are very helpful, and have been able to point me in the right direction. For example, one academic visiting India sent me numerous boxes of hard-to-find titles. This was very thoughtful, although I then had to catalogue and process them all!

Despite being here for a number of years now, I like to think of myself as still being fairly new. There is so much to learn about SOAS and its collections that $I$ haven't even begun to scratch the surface (I still don't know exactly what we have on the shelves!). Also, there has never been a law librarian at SOAS before and I've had to overcome some cataloguing and classification difficulties - for example, some records still don't have subject headings, which makes finding them via the catalogue difficult. l've also had to work hard to familiarise myself with the subjects and regions SOAS caters for, not only to order relevant materials, but also to help users with their research. I fear I shall forever be learning about the intricacies of the different legal systems.

My first task when I started was to tackle the English law section and expand the rather small collection I discovered on my appointment. That completed, I then undertook a move of all legal materials as the SOAS library underwent a minor face-lift. I can assure you that moving books around during the summer in temperatures of 36 degrees, without air conditioning, is not my idea of fun and something I wish to avoid in the future!

I'm now able to turn my attentions to the regional aspect of our collection and am working on several projects to improve both the collection and the catalogue records. I've found that I'm often asked for more recent cases and legislation from countries we (for one reason or another) don't collect any more. Therefore, one of these projects involves a review of all African legal materials, while future projects will review all Asian and Middle Eastern materials. These projects will be in collaboration with the Institute of Advanced Legal Studies (IALS), as it is important to ensure that there is no unnecessary duplication of collections. Unfortunately, it involves checking all materials within the region and sifting through very dusty shelves, although it does give me the opportunity to find out exactly what we have in the collections. As you might have guessed, this is quite a labour intensive project and will take some time to complete. However, it will help inform decisions about our future acquisitions, and I hope SOAS will be able to provide more, much needed resources to all its users.

Finally, if you contact me about wanting legal materials from Asia, Africa and the Middle East, I can't promise I will always find what you're looking for at SOAS but l'll make every attempt to do so.

\section{Biography}

Sarah Spells is the Principal Library Assistant for Law at the School of Oriental and African Studies. She has an LLB from Anglia Ruskin University, followed by an MSc in Information Science from City University. She has been working in academic law libraries since $200 \mathrm{I}$. She previously worked at the University of Hertfordshire before joining SOAS in 2003. She is a member of the BIALL Publications Committee, having just joined as an additional Newsletter Editor.

\section{Contact}

Sarah Spells: email ss 104@soas.ac.uk, telephone 02078984I55

Visit the Law Subject Guide at http://www.soas.ac.uk/library/law

Sarah Spells

Principal Library Assistant for Law

School of Oriental and African Studies

7 Thornhaugh Street

Russell Square

London, WCIH OXG 